\title{
Rental Relations as a Factor of Mining Investment Prospects
}

\author{
Gennady Alexandrov ${ }^{1}$, and Aleksandr Iablonev $^{1, *}$ \\ ${ }^{1}$ Tver State Technical University, 170026, Af. Nikitin Street, 22, Tver, Russia
}

\begin{abstract}
This article aims, first, to consider the conceptual question about the place and role of rental relations in subsoil use, particularly in the extractive industries and secondly, to determine the basics of scientific analysis of the essence and forms of rent and rent relations, generally, and mining rents in particular in aspect of their influence on the formation of a favourable investment climate in the extractive industry. Article is largely introductory in nature, so far as in theory and in practical terms, the problems of relationship rent relations and investment attractiveness of the extractive industries have not adequately attention. In this direction has never appeared in any relevant studies, the results of which could serve as the basis for formulating practical solutions, such as formation of adequate economic policies, rent relations regulatory frameworks, their organizational and legal security underlying the investment attractiveness of extractive activities.
\end{abstract}

\section{Introduction}

Creating a favourable investment climate in Russia's mining industry, without which you cannot count on it coming development, requires foremost, determine, firstly in order, what are the rental relations in general, subsoil use in particular and extractive activity in features. Secondly, to identify the nature and extent of the impact of the rental factor on formation of investment climate in the extractive industries. Thirdly, to consider possible directions of institutionalization of rental relations, transfering the past in specific organizational and economic forms and mechanisms, make adequate distribution and redistribution of income from the subsoil and, respectively, forming an attractive investment climate. In other words, the solution to the problem of sending of extractive activities on mainly the innovation way of development is largely associated with the creation of effective economic mechanism of realization of rental relations ensuring consensus between the interests of the owner of the natural resource and entrepreneur, developing this resource.

Without this you cannot form a favourable investment climate, ensuring high motivation and incentive to invest. In this article we put to consider theoretical bases of decision priority, in our view, two interrelated tasks. First of them is methodological in nature and caused by the need to overcome the discrepancies in understanding the essence of rent and rent relations, objectively emerging environmental

\footnotetext{
* Corresponding author: alvovich@mail.ru
} 
management in general and in the extractive field of activity in particular. The second task is to justify the way of reforming of organizational-economic rent relations and bringing them into line with their objective content. Their solution would create a reliable, adequate objective rental relations mechanism of rent regulation.

Above all, which is especially important in practical terms when forming such a mechanism, to overcome, on the one hand, primarily departmental, i.e. one-sided approach, originally based on not one common, that characterizes the rental relations in General and is their essence, but exclusively on the features each of the extractive industries. On another hand, to abandon the fiscal approach to regulation rent relations, which is used by the State, initiating fiscal interests to the fore. Both contrary to methodological principle in accordance with that must first be solved common questions, to when solving private questions inevitably and not at every step to stumble on these common issues. As it does not recall warning philosophers that watching private (specific), the man makes a hasty conclusion about what exactly is general (universal).

\section{Materials and methods}

With respect to the first task, then, first it is necessary to overcome significant differences in understanding rents as an economic category, representing certain economic relations, which, as you know, fold over the production, distribution and use of rent. They, in turn, are manifest both the interests of economic factors, holders of these relations, that is, the owners of natural resources and their users, entrepreneurs.

Moreover, here it is important to understand that exactly relations on land ownership and, accordingly, on entrails determine the nature of the subsoil rental relationships and their manifestation in the form of specific organizational and economic relations. Meanwhile, so far go debate on ownership of the subsoil and therefore how should line up relations of ownership, disposal and use of mining rents. The founders of classical political economy, directly pointed to the fact that, on the one hand, it is the ownership of land and subsoil itself led to the existence of the rent [1], and, on the other, starting with J.S. Mill, believed that the earth and the entrails are not created by humans and are the heritage of all people. Therefore, they must belong to society as a whole, be a matter of common usefulness and focus the general State policy. In other words, you cannot cite a single valid argument in favour of it was in general private property, and if someone is allowed to call his land, then such a person should know that he owns the land with the acquiescence of the society and on the intended arrange. Moreover, the State may deprive him of the right to land in the name of their interests [2]. Later, for example, the British philosopher and sociologist G. Spencer generally believed that return private land and subsoil to State "corresponds to the highest condition of civilization" [3].

Interestingly, not only the founders of classical political economy, but also representatives of other areas were similar or similar views on the issue of land ownership, believing that the theory of rent, "the true cornerstone of collectivist economy", so far as the results of the exploitation of the subsoil resources should benefit all citizens [4]. However, the discussions on the issue of ownership of natural resources continues to this day. Proponents of public ownership of the subsoil, the lead in her favor, except what was mentioned above, a number of arguments. Firstly, they believe that only the State can be an effective owner of the subsoil and ensure their rational exploitation, because the subsoil user, unlike land user is, by definition, minion. This property is due to the fact that minerals are largely non-reproducible resources, and each developed plot not only provided for a definite period of time, but also has its own life cycle.

Therefore, as noted by one of the economists, any investor Russian or even more foreign - will always be interested in maximizing the exploitation of plot with mineral 
resources, not excluding its predatory development [5]. In contrast, proponents of the alternative point of view believe that private ownership of land, including the subsoil is quite justified. For example, one of them believes that by doing so, the principle of social justice, because the landowner gets his in accordance with length of mental, organizational and managerial labour, i.e. in accordance with the action of eternal natural laws of Economics [6].

As you can see, the arguments in favour of an alternative perspective do not look too convincing, so much so that in countries with developed market economies the entrails are predominantly in public ownership. Thus, logically, when in modern society, the ownership and disposition of mineral resources reserved for the State, as a mouthpiece of all members of society, and in accordance with the possibilities, it could generate such system of organizational and economic relations that would be adequate to the objectively existing rental relations and was a form of expression.

In other words, assuming that the ownership and orders of remains for the State, it on certain market conditions gives the businessman the right to use, which must be paid for. The problem, highly debatable, is to understand in what form, to what extent, in what order, and by what economic mechanism of this payment will be made. And, as we see it, the solution requires order accounting objective fact, coupled with the reality, that the latter are formed, and the rent is raised directly in the production process, i.e. the process of implementing the extractive activities. Distribution relations and attribution of results from this activity, entrepreneurial income and rents, which assign a license holder and owner respectively, are derived from industrial relations.

At the same time, it should be borne in mind that between private entrepreneurs as resource users and the owner of the subsoil - State objectively there are contradictions in interests, as far as the first interested in maximizing business income and the latter to maximize rents. Therefore, there is always the abstract possibility of real conflicts between the subsoil user and State, if the regulating role of the latter is not adequate from the perspective of the balance of interests of both subjects of rental relations that, ultimately, substantially and adversely affects the motivation and incentives of subsoil users to invest. For more detail about this, see [7, 8]. It appears that to resolve this problem, you should apply to the entity rents and rent relations. However, these issues remain controversial and it has not achieved any acceptable level of agreement among researchers.

\section{Results and discussion}

The fact of the matter is that with the beginning of the development of a market economy in Russia, neo-classical economists from the direction of political economy often prefer to pretend that the concept of rent, representatives of classical political economy, expanded at essence level, does not exist. On the one hand, as rightly noted by economists, many from the classics included in neoclassicism without any reference to borrowing from their opponents. On the other, many studies of rent relations are maintained over a wide range of natural rents to various forms of quasi-rents.

As a result, there is an expanded understanding of the rents, which are presented in different new forms, often essentially very little in common with the real rent. They are represent quasi-rents and its classification as a novation, designed in full compliance "with the modern concepts of science, economy and society development" and include in it more and more new forms and varieties of rents. For example, such as technological, political and criminal, space, energy, frequency oligopolistic, etc. As new species represented too: chemical mining, well, oil and gas mining rent. These classifications are based on the principle that any income or its shape (for example, lease pay, profit, etc.) in their understanding might be recognized as rental, if its relative value is significantly higher than 
normal or average level. Or if any additional income obtained by the owners of the resource more effectively as a differential quasi-rents.

Thus, represented in the modern Russian literature many forms of rent and rentsorganizing resources, blurs the economic content and lifts it from the objective factors contributing to rent. As a result, these new forms of rent proved to be virtually, lost primary character of its production, and the proposed classification of rents only confuses and complicates the process of disclosing its essence. Between rents and its modern classifications, i.e. purely external forms, lost logical link, and the last remains methodologically unsound and uncertain. It should be noted that even such famous representatives of "Economics", as C.R. McConnell and S.L. Brue, speak critically about the quasi-rents, pointing out that this kind of determination of rents are not entirely clear and ambiguous.

Therefore, they argue, economists use the term "rent" in the narrower and less ambiguity in the meaning of, namely, as the price paid for the use of land and other natural resources, what quantity (their stocks) strictly limited [9]. Further analysis of the definitions of the various contemporary forms of rent doesn't make much sense, because, as can be seen from the above, there is no opportunity to establish a logical connection between these forms, organizational-legal relations and mechanisms of distribution and exceptions of this kind of rent. In solving the second issue, namely, justification of the ways of reforming the organizational and economic rental relations and, thereby, ensure consensus among all subjects of rental relations, we believe that specific forms and methods of rent control, regulation of relations should be withdrawn (emphasized by us authors) from the analysis of mining rents essence and objectively rent relations. As regards for the concept of differential rent, its ancestor is A. Smith: "...Rents, which can give its owner that or another mine, he wrote, does not depend on its absolute, and, so to speak, from the relative wealth or excess extraction in comparison with other mines the same kind» [10]. Therefore, as David Ricardo: "... the income of the poorest mine delivered not paying any rent will regulate the rents of all other more productive mines. It is anticipated that this mine gives a normal return on capital. All that other mines give over her, will, of course, be paid to their owners as rent» [11].

If you accept these provisions, and nobody has so far denied, it appears that in the basis of the forms and withdrawal mechanism of rent in favor of the owner of the subsoil, the State, must be put on residual principle. The gist of it is that the entrepreneur, as a user of subsoil, as a matter of priority, will pay the rents arising from the agreement, and the remaining part of the profit will appropriate in the form of entrepreneurial income [7]. In fact, K. Marx noted that profit is not the border of the rent and the rent is the boundary of profit [1]. However, implementation of this approach, in order to ensure the necessary consensus for the interests of the owner of the subsoil and entrepreneur, as well as the investment attractiveness of extractive activities, due to the decision by at least two problems. To the fore on its relevance, is the problem of the allocation of rents, as incremental income by natural conditions, from gross profit generated by extractive activities. A further problem arises is determining amount and order of seized State rental income depending on the nature of the tasks in the subsoil use, including tasks, motivating and stimulating the inflow of investments [12]. With regard to the first problem, as noted above, mining rents definition seems inappropriate here as the difference between the profits of mining production, received from the realization of the extracted from the depths of the product and the normal profits of mining production [13]. Such an approach might well be adversely affected the interests of the owner of the subsoil, while an entrepreneur when inflated compared to medium-branch levels of production costs, increase their business revenue, "climbing up" in rent. Conversely, if the public of normal conditions of production are respected, but entrepreneur receive less part should him profit, due to 
oversized rents withdrawn by the owner of the subsoil, the subsoil user may completely divide the desire to invest.

To resolve this contradiction, as we see it, you can only by using the factorial approach. Namely, what proportion of the gross profit is created under the influence of natural factors? It is understandable that when developing the worst quality of deposits, this part is equal to zero. You can find various proposals on the definition of rent and business income in scientific publications. They are based on inventory [14-17] and the value approaches [18]. We have developed and proposed natural-value approach, including algorithm, which seems more conducive to escape from the residual principle determining rents [7, 12]. With regard to the issue of the size and order seized in favour of the State rental income, then as noted above, both of which is a matter of economic policy of the State as the owner of the subsoil. That is, it acts as a regulator of rental relations by setting the size of rental payments, which by its quantity, for example, when performing their incentive functions, can be lower than the amount actually produced rent. And may, under certain circumstances, be higher. In addition it includes the principle of correction seized rents as the geological environment of mining get worse, and accordingly, takes into account the effect of the objective law of diminishing return deposits.

\section{Conclusion}

Thus, the article describes scientific approaches to the analysis of rents and rental arrangements. Disclosed those aspects, the study of which will formulate a holistic concept of rental relations in mining production. Received during the research results are important, both theoretically and practically. Based on provided conception, a real opportunity to develop a number of practical measures to reform an organizationally-economic relations and the establishment of an efficient mechanism for regulating rent relations in environmental management appears. They should enhance the investment attractiveness of the extractive industries, determine the greater motivation and interest of business entities in enhancing its investment activities, aimed at mainly innovative development of the extractive industry. Admittedly, it is a weak motivation and lack of real incentives arising from the low attractiveness of the investment climate prevent this $[19,20]$.

\section{References}

1. P. Mollin, Classical theory if mining rent (Collman, London, 1999)

2. J. S. Mill, Principles of Political Economy (Oxford University Press, Oxford, 2008)

3. H. Spenser, Principals of Sociology (Appleton \& Co., New York, 1898)

4. C. Gide, C. Rist A History of Economic Doctrines (George G. Harrap \& Co., New York, 1961)

5. S. A. Kimelman, S.A. Andrushin, Problems of Economic Transition, 2, 83-92 (2005)

6. I. N. Buzdalov, Problems of Economic Transition, 3, 24-35 (2004)

7. G. Alexandrov, A. Yablonev, E3S Web of Conferences 21, 04011 (2017)

8. G. A. Aleksandrov, T. B. Yakonovskaya, I. V. Vyakina, G. G. Skvortsova, Eur. Sci. Rev., 11-12, 96-100 (2014)

9. C. R. McConnell, S. L. Brue, Economics. Principles, Problems and Policies (McGrawHill, New York, 1990)

10. A. Smith, An Inquiry into the Nature and Causes of the Wealth of Nations (Colin Muir and David Widger, London, 2009). 
11. D. Ricardo, Compositions (John Ramsay McCulloch, London, 1846)

12. G. A. Alexandrov, A. L. Yablonev, Min. J. (to be published)

13. J. Schumpeter, A History of Economic Analysis (Oxford University Press, Oxford, 1954)

14. G. E. Ortega, A. Pugachevsky, G. Walser, Mineral rights cadastre. Oil, Gas and Mining Policy Division of the World Bank (NGAAD, Washington, 2009)

15. V. V. Matyukha, Min. J., 7, 60-62 (2014)

16. S. I. Nosov, B. Ye. Bondarev, I. B. Gengut, O. I. Chernyahovsky, Min. J., 2, 51-55 (2016)

17. M. Nieć, K. Galos, K. Szamałek, Resources Policy, 42, 93-103 (2014)

18. N. V. Galtseva, O. A. Sharipova, I. S. Golubenko, I. N. Grigoryeva, Min. J., 3, 27-32, (2016)

19. C. P. Jones, Investments: Analysis and Management (John Wiley \& Sons Inc., London, 2012)

20. G. A. Alexandrov, I. V. Vyakina, G. G. Skvortsova, Act. Prob. Econ., 3:165, 415-428 (2015) 